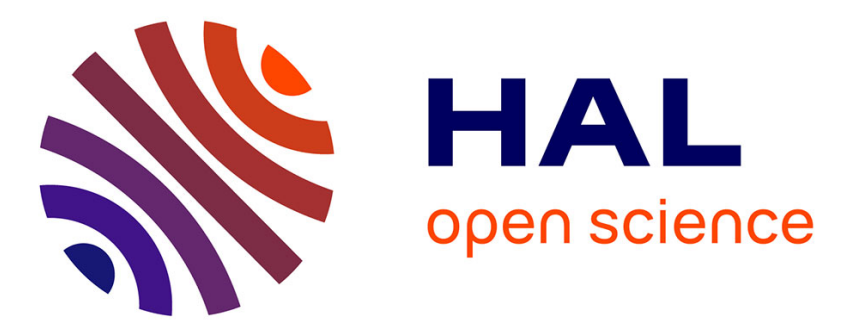

\title{
Adult Perception of Gender-Based Toys and Their Influence on Girls' Careers in STEM
}

Serena Lee-Cultura, Katerina Mangaroska, Kshitij Sharma

\section{To cite this version:}

Serena Lee-Cultura, Katerina Mangaroska, Kshitij Sharma. Adult Perception of Gender-Based Toys and Their Influence on Girls' Careers in STEM. 17th International Conference on Entertainment Computing (ICEC), Sep 2018, Poznan, Poland. pp.407-410, 10.1007/978-3-319-99426-0_52 . hal02128620

\section{HAL Id: hal-02128620 \\ https://hal.inria.fr/hal-02128620}

Submitted on 14 May 2019

HAL is a multi-disciplinary open access archive for the deposit and dissemination of scientific research documents, whether they are published or not. The documents may come from teaching and research institutions in France or abroad, or from public or private research centers.
L'archive ouverte pluridisciplinaire HAL, est destinée au dépôt et à la diffusion de documents scientifiques de niveau recherche, publiés ou non, émanant des établissements d'enseignement et de recherche français ou étrangers, des laboratoires publics ou privés. 


\title{
Adult Perception of Gender-Based Toys and their Influence on Girls' Careers in STEM
}

\author{
Serena Lee-Cultura ${ }^{1}$, Katerina Mangaroska ${ }^{1}$, and Kshitij Sharma ${ }^{1}$ \\ Norwegian University of Science and Technology, Trondheim 7034, Norway
}

\begin{abstract}
STEM and Computer Science (CS) in general, are perceived as masculine disciplines; a dangerous fallacy that discourages girls to show interest in the domain. However, companies are moving towards designing toys to attract and educate girls about science. Consequently, this study tries to explore adults perception of gender packaged toys (e.g. Barbie) and their intervention potential for engaging more girls in CS. Results show that old Barbie used to convey shallow ideals to young girls, placing emphasis on fashion and appearance. On the other hand, the new Barbie themed programming course has the power to attract more girls into CS.
\end{abstract}

Keywords: Gender - Toys - Computer Science - STEM

\section{Introduction}

The perception of Computer Science (CS) as an inherently masculine discipline is a dangerously ubiquitous fallacy that discourages female's sense of ambient belonging and subsequent interest in the domain $[2,3]$. From an early age, the majority of girls are diverted from STEM associated disciplines and future careers [4]. One such example can be found in implicit messages delivered by gender stereotyped toys [12]. Moreover, Barbie is of notable concern as her negative ability to promote self objectification and sexualization of self, reduces the breadth of future career options a young girl can envision for herself [12].

However, there have been societal protest over toys like Teen Talk Barbie, who enthusiastically claims that "math is tough", and the more recent "I can be a computer engineer" Barbie book, in which she infects her laptop with a virus, and laughs at her lack of ability to find quick and clever ways to overcome difficulties. This same Barbie depends on her male friends to program a game on her behalf, underlining the societal stereotype about female lack in ingenious ways to handle science [7]. Cheryan et al. argue that to strengthen female interest in CS and engineering, the focus should be to diversify the existing stereotypes to be more representative of an inclusive culture [2]. In an effort to synchronize with the changing academic and societal mindset, companies are moving towards designing toys to attract and educate girls about science.

Consequently, the aim of this study is to examine the perceptions of gender packaged toys and their intervention potential for increasing female engagement 
in STEM, in particular CS education, perceived from an adult frame of reference. Participants consisted of 12 adults, 6 females and 6 males, who watched a video from Barbie's vlog. In the vlog, Barbie encourages viewers to follow their dreams and pursue education and professions in science by discussing a highly accomplished female scientist and engineer. Results showed that although Barbie's vlog was positively accepted by all participants, female and male perspectives regarding a Barbie themed programming curriculum as tool to attract young girls into CS professions differed largely; women supported the idea (5/6), while male opinions were split $(3 / 6)$.

\section{Background}

Past research has emphasized the role of early childhood education (ECE) in building the foundation for gender-based behavior and academic preferences that encourage children to undertake a particular learning path [13]. As mentioned in Sherman and Zurbrigge's work, "children build cognitive schemas for understanding their world and learn early that gender is a critically important lens for organizing information and influencing behaviour" [12]. Moreover, the process of gender role socialization through which children learn to abide by culturally prescribed norms, is stimulated by playing with gender-oriented toys. As a result, children learn about "gender differences" and "gender-appropriate" behaviors, which collectively represent a serious issue by increasing the gender gap in future education and professions [4,9]. For example, studies show that while girls are often given toys associated with domestic or mothering activities, boys are typically provided toys that encourage exploration, invention, or assembly behaviors $[1,6]$. Consequently, these studies observed differences among genders in cognitive processing and problem-solving strategies [11].

Broadly speaking, toy differentiation with respect to gender, reinforces the cultural ideals demonstrated via media; in particular, a girl's role in society and societal expectations of her appearance and behaviour [12]. One such example is Barbie. According to McKnight, Barbie sends cultural messages and defines expectations that are potentially damaging for girls developing self-concepts [8]. Furthermore, results from one study indicated that the girls who played with Barbie identified a significantly reduced number of future career opportunities for themselves relative to the occupation possibilities they considered for boys when compared to the Mrs Potato Head control group [12]. In contrast to aforementioned studies, recent years have birthed a new era of toys and technologies purposed to interest young girls in STEM related concepts. One such example is GoldieBlox; a doll exclusively marketed to young girls, purposed to promote female engagement with engineering concepts $[5,10]$. Consequently, the main objective of our study is to develop a deeper understanding how adults perceive gender packaged toys and to consider the use of gender packaged toys as a successful intervention technique for attracting more girls into STEM related fields over time. 


\section{Case study set up}

During spring 2018, an experiment was performed at a contrived computer lab setting at Anonymous University with $12 \mathrm{CS} \mathrm{PhD}$ students (6 females and 6 males). The mean age of the participants was 31 years (Std. Dev. $=4.96$ years). Upon arrival in the laboratory, the participants signed an informed consent form and filled in a pre-questionnaire regarding their attitudes towards gender-based toys. Then, the participants were required to watch a 2 minute Barbie vlog video, titled "You Can Be Anything or Everything!". After watching the video, the participants were asked to complete a post-questionnaire about their attitudes towards gender-based toys. As previously mentioned, the aim of the study was to examine adults perceptions of gender packaged toys and their intervention potential for engaging more girls in STEM education, in particular, CS education.

\section{Discussion and future directions}

The pre-questionnaire revealed that initially none of the participants viewed Barbie to be a good female role model. However, during the 80s and 90s, the Barbie franchise was primarily focused on the doll itself and lacked motivational online content. Considering this precursory image of Barbie, female participants described Barbie as conveying shallow ideals to young girls, placing emphasis on fashion and appearance (specifically being "slim" and "beautiful"), and defining female success through attainment of men. Male participants supported the same perspective, underlining that Barbie teaches girls to be pretty, stylish, wear make-up and be constantly happy. In addition, both male and female participants agreed that Barbie also teaches young boys that girls should dress nicely, be clean, and beautiful. However, despite initial attitudes opposing Barbie as a female role model, the "You Can Be Anything or Everything!" video was positively accepted by all participants, especially females, who described it as "inspiring", "impressive and useful". Half of the female and male participants improved their attitude towards Barbie's impact as a female role model (this includes going from negative to positive, neutral to positive, or negative to neutral).

Building upon this, another interesting finding showed that although prior to watching the video only a third of the female participants (and none of the male participants) indicated that Barbie demonstrated the potential to encourage girls into CS through positive gender association, after watching the video, $80 \%$ of female participants (and $50 \%$ of the male participants) agreed that a Barbie themed programming course had the power to attract more girls into CS. This demonstrates that participants support Cheryan et al. recommendation to diversify the perception of computer scientist to attract more girls into CS [2]. Moreover, it shows support extending on research claiming that toys

can be used to influence career choice [4] and that children program and create games based on their favorite toys, stories or movies characters. Finally, it is 
worth mentioning that two of the male participants said that to get girls into CS we need societal transformation that will bring children and adults together into making change that will have a positive and long-term impact.

In summary, the study demonstrates potential for further exploration of adults attitudes towards gender-based toys and technique for attracting more girls into STEM related fields, specifically CS. In future studies, we plan to use EEG, eye-tracking and wristbands to gather insights into the emotional state of the participants. Furthermore, we also plan to repeat the study on children to investigate their attitudes towards gender-based toys and the new incarnation of Barbie.

\section{References}

1. Bradbard, M.R.: Sex Differences in Adults' Gifts and Children's Toy Requests at Christmas. Psychological Reports 56(3), 969-970 (1985)

2. Cheryan, S., Master, A., Meltzoff, A.N.: Cultural Stereotypes as Gatekeepers: Increasing Girls Interest in Computer Science and Engineering by Diversifying Stereotypes. Frontiers in Psychology 6, 49 (2015)

3. Cheryan, S., Plaut, V.C., Davies, P.G., Steele, C.M.: Ambient Belonging: How Stereotypical Cues Impact Gender Participation in Computer Science. Journal of Personality and Social Psychology 97(6), 1045 (2009)

4. Cooper, S.E., Robinson, D.A.: Childhood Play Activities of Women and Men Entering Engineering and Science Careers. The School Counselor 36(5), 338-342 (1989)

5. Coyle, E.: Influences on Children's Play with a STEM Toy: Interactions Among Children, Parents, and Gender-Based Marketing. Ph.D. thesis, Pennsylvania State University (2015)

6. Fagot, B.I.: Sex Differences in Toddlers' Behavior and Parental Reaction. Developmental Psychology 10(4), 554 (1974)

7. Godwin-Jones, R.: Emerging Technologies the Evolving Roles of Language Teachers: Trained Coders, Local Researchers, Global Citizens. Language, Learning and Technology 19(1), 10-22 (2015)

8. McKnight, L.: Still in the LEGO (LEGOS) Room: Female Teachers Designing Curriculum Around Girls Popular Culture for the Coeducational Classroom in Australia. Gender and Education 27(7), 909-927 (2015)

9. Miller, C.L.: Qualitative Differences Among Gender-Stereotyped Toys: Implications for Cognitive and Social Development in Girls and Boys. Sex Roles 16(9-10), 473-487 (1987)

10. Mueller, U.: Advancing Developmental Science: Philosophy, Theory, and Method. Taylor \& Francis (2017)

11. Rubin, K.H.: The Social and Cognitive Value of Preschool Toys and Activities. Canadian Journal of Behavioural Science/Revue Canadienne des Sciences du Comportement 9(4), $382(1977)$

12. Sherman, A.M., Zurbriggen, E.L.: Boys can be Anything: Effect of Barbie Play on Girls Career Cognitions. Sex Roles 70(5-6), 195-208 (2014)

13. Welsh, M.E., Miller, F.G., Kooken, J., Chafouleas, S.M., McCoach, D.B.: The Kindergarten Transition: Behavioral Trajectories in the First Formal Year of School. Journal of Research in Childhood Education 30(4), 456-473 (2016) 